A Publication of the Materials Research Society

Volume 22, Number 2 ISSN : 0883-7694 CODEN: MRSBEA

GaN AND RELATED MATERIALS FOR DEVICE APPLICATIONS

17 GaN and Related Materials for Device Applications

S.J. Pearton and C. Kuo, Guest Editors

22 Reactive Molecular-Beam Epitaxy for Wurtzite GaN

S.N. Mohammad, W. Kim, A. Salvador, and H. Morkoç

29 Blue-Green Light-Emitting Diodes and Violet Laser Diodes

S. Nakamura

36 Implantation and Dry Etching of Group-III-Nitride Semiconductors

J.C. Zolper and R.J. Shul

44 GaN/AIGaN Heterostructure Devices: Photodetectors and Field-Effect Transistors M.S. Shur and M.A. Khan

51 Defects and Interfaces in GaN Epitaxy

F.A. Ponce

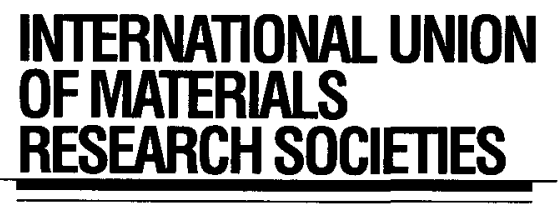

58 ICAM'97/E-MRS'97 to Be Held in Strasbourg, France

\section{MRS NEWS}

59 Preview: 1997 MRS Spring Meeting

60 Peercy to Give Plenary Speech on the Future of Semiconductor Research

60 Bowman Receives OYI Award for Work on Polymers

\section{ABSTRACTS}

77 Abstracts for April 1997 Journal of Materials Research

84 Abstracts of MRS Internet Journal of Nitride Semiconductor Research, Volume 1, Articles 1-14

\section{DEPARTMENTS}

5 Material Matters

8 Research/Researchers

12 Washington News

13 Public Affairs Forum

15 Resources

16 Editor's Choice

35 Advertisers in This Issue

73 Historical Note

75 Library

87 Classified

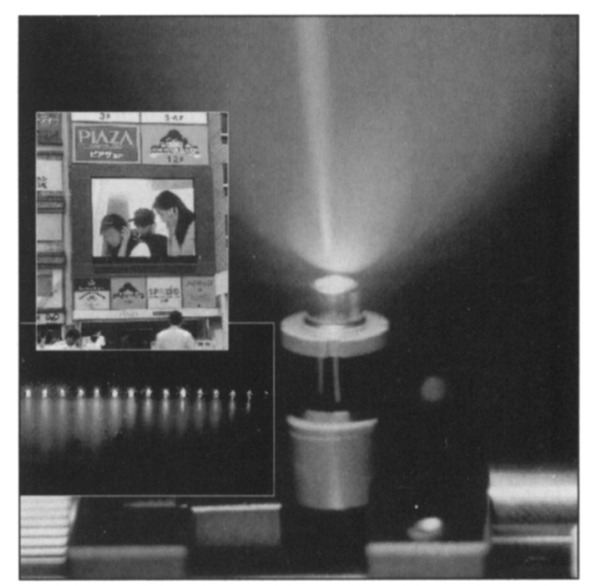

ON THE COVER: Blue GaN-based laser diode operated at room temperature under pulsed conditions. TOP INSET: Outdoor display in downtown Takyo, utilizing GaN light-emitting diodes. BOTTOM INSET: GaN-based lightemitting diodes of different InGaN composition, leading to colors from blue to yellow. For more information, see the section that begins on page 17. 


\section{Alout the Materials} Research Society

The Materials Research Society (MRS), a nonprofit scientific association founded in 1973 promotes interdisciplinary goal-oriented basic research on materials of technological importance. Membership in the Society includes over 12,000 scientists, engineers, and research managers from industrial, government and university research laboratories in the United States and nearly 50 countries.

The Society's interdisciplinary approach differs from that of single-discipline professional societies because it promotes information exchange across the many technical fields touching materials development. MRS sponsors two major international annua meetings encompassing approximately 60 topical symposia, and also sponsors numerous single-topic scientific meetings. The Society recognizes professional and technical excellence and fosters technical interaction in local geographic regions through Sections and University Chapters.

MRS participates in the international arena of materials research through the International Union of Materials Research Societies (IUMRS). MRS is a member of the Federation of Materials Societies and is an affiliate of the American Institute of Physics.

MRS publishes symposium proceedings, MRS Bulletin, Journal of Materials Research, and other publications related to current research activities.

MRS Bulletin (ISSN: 0883-7694) is published 12 times a year by the Materials Research Society, 9800 McKnight Road, Pittsburgh, PA 15237. Application to mail at periodicals rates has been approved at Pittsburgh, PA and at additional mailing offices. POSTMASTER: Send address changes to MRS Bulletin in care of the Materials Research Society, at the address listed; phone (412) 367-3003; fax (412) 367-4373. Printed in the U.S.A.

Additional copies of articles in MRS Bulletin may be made at $\$ 2.50$ per article. This fee can be paid to the Materials Research Society through the Copyright Clearance Center, Inc. 27 Congress Street, Salem, MA 01970.

Membership in MRS is $\$ 75$ annually for regular members, \$25 for students. Dues include an allocation of $\$ 29$ ( $\$ 17$ for students) to a subscription to MRS Bulletin. Individual member subscriptions are for personal use only. Non-member subscription rates are $\$ 135$ for one calendar year (12 issues) within the U.S.A. and \$185 elsewhere. Single copies may be purchased for $\$ 16$ each. Send subscription orders to Subscription Department, Materials Research Society, 9800 McKnight Road, Pittsburgh, PA 15237.

MRS Bulletin is included in Current Contents ${ }^{\omega} /$ Engineering, Computing, and Technology; Current Contents'/Physical, Chemical, and Earth Sciences, the SciSearch" online database, Research Alert", Science Citation Index", and the Materials Science Citation Index'. Back volumes of MRS Bulletin are available in $16 \mathrm{~mm}$ microfilm, $35 \mathrm{~mm}$ microfilm or $105 \mathrm{~mm}$ microfiche through University Microfilms Inc., 300 North Zeeb Road, Ann Arbor, Michigan 48106.

Materials Research Society 9800 Mcknight Road Pittshurgh, PA 15237-6006

Tel. (412) 367-3003; Fax (412) 367-4373 http://www.mrs.org/

Editorial Office • 9800 McKnight Road • Pittsburgh, PA 15237-6006

Tel. (412) 367-3004 x522; fax (412) 367-4373; htip://www.mrs.org/

Editor

E.L. Fleischer

Managing Editor

J. Meiksin

Assistant Editor

L.R. Gallagher

Art Director

E. Stiller

Design/Production

T. Aiello and S. Franklin

Editorial Assistants

J. Dininny and

M. Wilmoth
Advertising

M.E. Kaufold

Circulation

B.J. Alcorn

Guest Editor

S.J. Pearton and C. Kuo

Special Contributors

1. Amato, S. Beckerman

V.M. Oversby, J.M. Phillips,

and L.A. Snyder

Special Consultant

M. Goodway
Associate Editor-Europe

I.W. Boyd

University College London

Dept. of Electronic and

Electrical Engineering

Torrington Place

London WCI E7 JE U.K

Tel. $44-171-380-7300$ or 7302

Book Review Editor

C.J. McHargue

University of Tennessee

Knoxville, Tennessee

MRS Office of Public Affairs

555 13th Street NW. Suite 900 East

Washington, DC 20004

Tel. (202) 383-8809, Fax (202) 383-8877

CHAIR-EDITORIAL BOARDS

E.N. Kaufmann • Argonne National Laboratory • Argonne, Illinois, USA

\section{INTERNATIONAL ADVISORY BOARD}

M. Balkanski

University of Pierre and Marie Curie

Paris, France

R.G. Elliman

Australian National University

Canberra, Australia

S. Hsu

Chung Shan Institute of Science

and Technology, Retired

Taiwan, China

\section{TECHNICAL EDITORIAL BOARD}

\section{L.C. Ianniello \\ U.S. Department of Energy, Retired Washington, DC, USA}

H-D. Li

National Science Foundation-China Beijing, China

P. Rama Rao

Ministry of Science and Technology New Delhi, India
R. Roy

The Pennsylvania State Universit

University Park, Pennsylvania, USA

T. Sugano

Toyo University

Tokyo, Japan
J.C. Bravman

Stanford University

Stanford, California, USA

C.W. Draper

AT\&T Engineering Research Cente

Princeton, New Jersey, USA

E. Fogarassy

Centre de Recherches Nucléaires

Strasbourg. France

\section{F.Y. Fradin}

Argonne National Laboratory

Argonne, Illinois, USA

B.M. León

Universidad de Vigo

Vigo, Spain

G.L. Liedl

Purdue University

West Lafayette, Indiana, USA
S. Namba

Nagasaki Institute of Applied Science

Tokyo, Japan

A.D. Romig Jr.

Sandia National Laboratories

Albuquerque, New Mexico, USA

J. Soares

Universidade de Lisboa

Lisboa, Portugal

K.C. Taylor

General Motors R\&D Center

Warren, Michigan, USA

MRS BULLETIN PUBLICATIONS SUBCOMMITTEE

M. Nastasi, Chair

Los Alamos National Laboratory

Los Alamos, New Mexico

F.W. Clinard

os Alamos National Laboratory

Los Alamos, New Mexico

R.C. Ewing

University of New Mexico

Albuquerque, New Mexico

\section{R.L. Fleische}

Rensselaer Polytechnic Institute

Troy, New York

A.J. Hurd

Sandia National Laboratories

Albuquerque, New Mexico

M. Libera

Stevens Institute of Technology

Hoboken, New Jersey

\section{F. Shapiro}

Drexel University

Philadelphia, Pennsylvania

C.W. White

Oak Ridge National Laboratory

Oak Ridge, Tennessee

\section{MRS EXECUTIVE COMMITTEE}

\section{President}

R. Hull

University of Virginia

Vice President and President-Elect

R.J. Nemanich

North Carolina State University

Secretary

K.S. Jones

University of Florida

\section{Treasurer}

A. Hurd

Sandia National Laboratories

Immediate Past President

C.V. Thompson

Massachusetts Institute of Technology
Councillors

R. Gibala

University of Michigan

A.I. Taub

Ford Research Laboratory

Executive Director

Materials Research Society

John B. Ballance
President

M. Doyama

Nishi-Tokyo University

Tokyo, Japan

Vice President
$\mathrm{H}-\mathrm{D}$. Li
Tsinghua University
Beijing, China

\section{INTERNATIONAL UNION OF MATERIALS RESEARCH SOCIETIES}

Secretary
C. Li
Aviation Industries of China
Beijing, China

G.M. Crean

University College

Cork, Ireland

mmediate Past President

P. Siffert

Centre de Recherches Nucléaires

Strasbourg, France
IUMRS ADHERING BODIES

Australian Materials Research Society (A-MRS)

J.S. Williams, Australian National University

Chinese Materials Research Society (C-MRS)

$\mathrm{H}-\mathrm{D}$. Li, Tsinghua University

European Materials Research Society (E-MRS)

I.W. Boyd, University College London, UK

Materials Research Society (MRS)

R. Hull, University of Virginia 


\section{III-Nitride Technology}

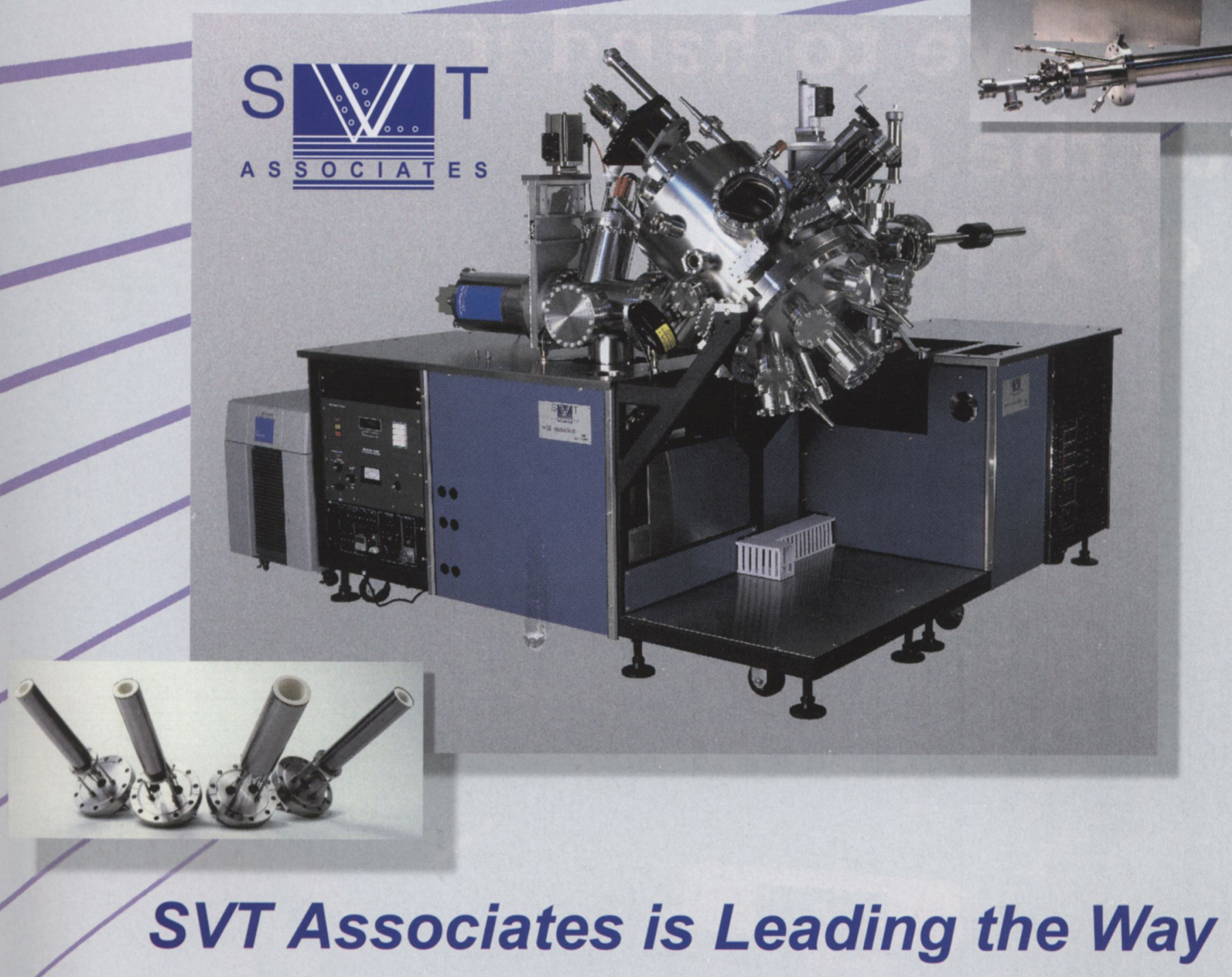

We offer:

- The first III-Nitride MBE system with guaranteed material specifications

- MBE components

- In-situ characterization techniques

- A laboratory for epi-growth services

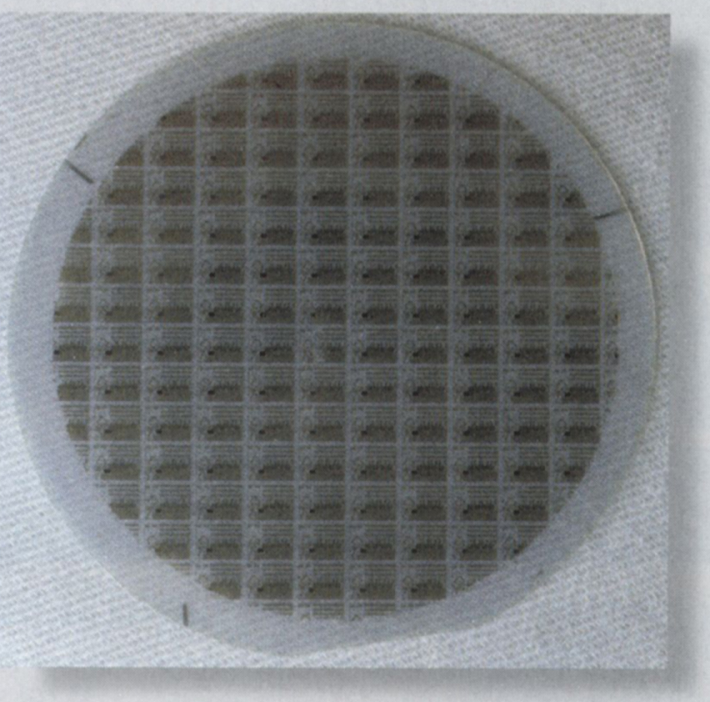




\section{You have to hand it}

\section{to the designers of X'Pert-MRD}
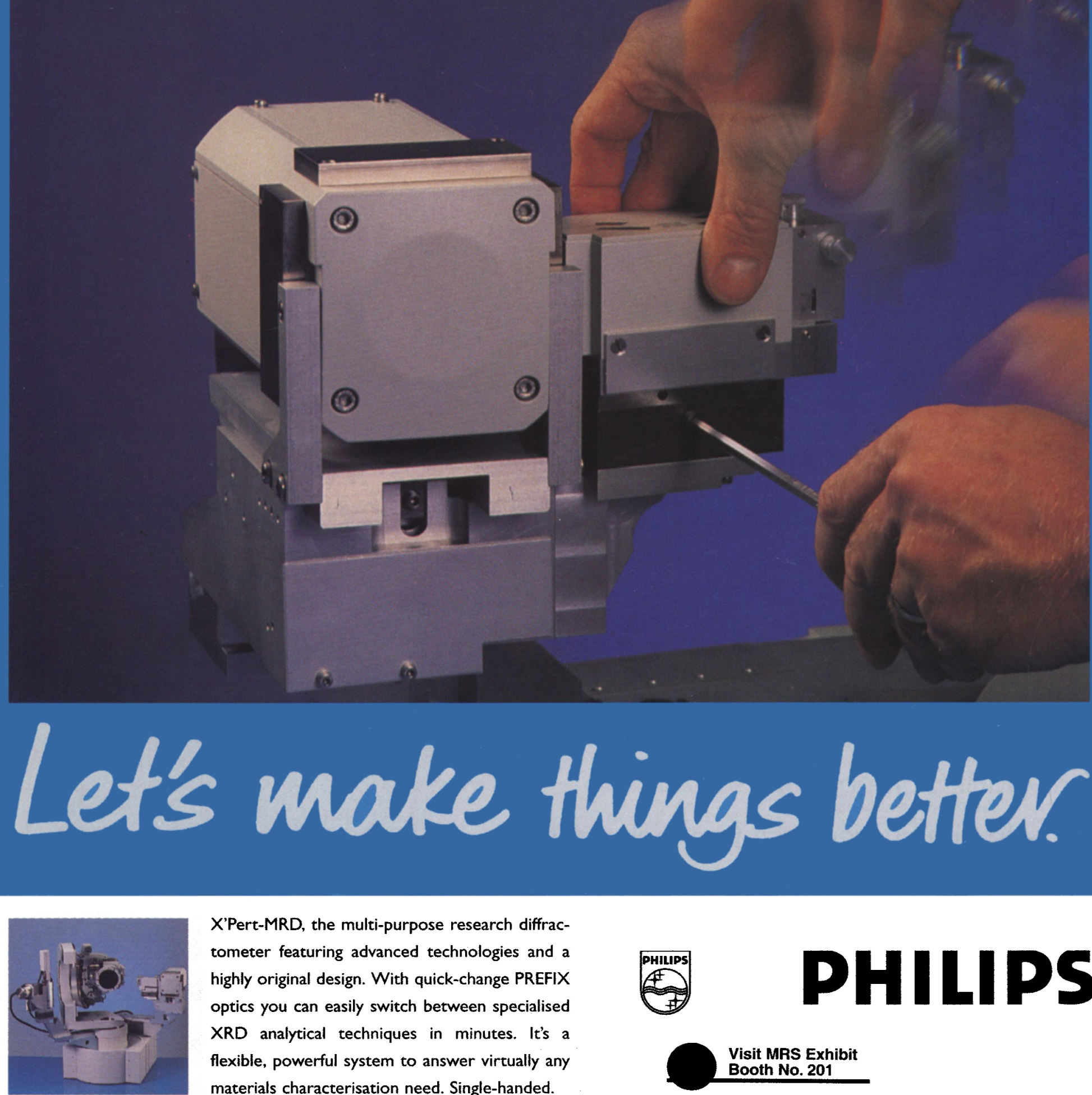

X'Pert-MRD, the multi-purpose research diffractometer featuring advanced technologies and a highly original design. With quick-change PREFIX optics you can easily switch between specialised $X R D$ analytical techniques in minutes. It's a flexible, powerful system to answer virtually any materials characterisation need. Single-handed.

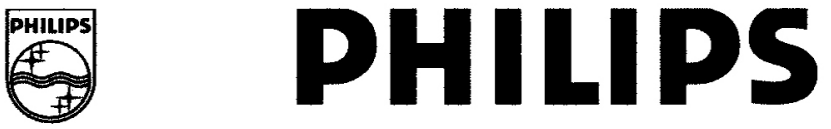

Visit MRS Exhibit

Booth No. 201 